Abstracta Iranica Iranica

Revue bibliographique pour le domaine irano-aryen

Volume 40-41 | 2019

Comptes rendus des publications de 2017-2018

\title{
Josef Wiesehöfer. “Anmerkungen zu Literalität und Oralität im teispidisch-achaimenidischen Iran"
}

\section{Reinhard Pirngruber}

\section{(2) OpenEdition}

12 Journals

\section{Electronic version}

URL: http://journals.openedition.org/abstractairanica/50052

DOI: 10.4000/abstractairanica.50052

ISBN: 1961-960X

ISSN: 1961-960X

Publisher:

CNRS (UMR 7528 Mondes iraniens et indiens), Éditions de l'IFRI

Electronic reference

Reinhard Pirngruber, "Josef Wiesehöfer. "Anmerkungen zu Literalität und Oralität im teispidisch-

achaimenidischen Iran"', Abstracta Iranica [Online], Volume 40-41 | 2019, document 82, Online since 30 December 2019, connection on 16 April 2021. URL: http://journals.openedition.org/abstractairanica/ 50052 ; DOI: https://doi.org/10.4000/abstractairanica.50052

This text was automatically generated on 16 April 2021.

Tous droits réservés 


\title{
Josef Wiesehöfer. "Anmerkungen zu Literalität und Oralität im teispidisch-achaimenidischen Iran"
}

\author{
Reinhard Pirngruber
}

\section{REFERENCES}

Josef Wiesehöfer. “Anmerkungen zu Literalität und Oralität im teispidischachaimenidischen Iran" in Anne Kolb (ed.). Literacy in Ancient Everyday Life. Berlin \& Boston: Walter de Gruyter, 2018, p. 99-111

1 The A. provides an overview of the languages attested in some kind of official capacity, including Old Persian, Imperial Aramaic and Achaemenid Elamite, and their respective uses in the Achaemenid Empire. He briefly tackles the question of multilingualism and the role of translator-scribes in the administration, and emphasizes the role of the spoken word in the Ancient Iranian world until deep into the Sasanian period.

\section{AUTHORS}

REINHARD PIRNGRUBER

Institut für Orientalistik, Wien 